\title{
The personal is political in Kinuta o utsu onna [The cloth fuller]: A 'little narrative' by zainichi Korean writer Lee Hoe Sung ${ }^{1}$
}

\author{
ELISE FOXWORTH
}

Abstract

In 1971 Japan-based second-generation Korean writer Lee Hoe Sung became the first 'foreigner' in Japan to win the esteemed Akutagawa Prize for Belles Lettres for his semi-autobiographical novel Kinuta o utsu onna [The cloth fuller]. It recounts the life and death of a young Korean woman, Chang Suri, during the 1940s, as remembered by her son. Whilst fascism, democracy, and Korean nationalism constitute the meta-narratives that informed the lives of Lee's generation in (post)colonial Japan between the 1940 s and 1960s, the writer underscores the importance of the little narrative for exploring identity and a sense of belonging. Eschewing hyper-political approaches that attempt to explain the whole movement of history and social life or nationhood as a 'grand narrative', Lee's poignant rendition of the life and death of a young woman is rather a 'little narrative' of personal suffering and redemption. Lee's story functions as a sinse t'aryong (i.e., a traditional Korean form of oral lamentation and narrative storytelling), which allows him to point to 'Korean-ness' as an anchor. This anchor secures the listener to a solid 'home' or cultural place of reference that can support them in their search for a sense of identity and belonging in the context of colonialist oppression and dislocation.

Keywords: zainichi Korean literature; Japanese literature; postcolonialism; little narrative; sinse t'aryong; lamentation; Lee Hoe Sung.

\section{Introduction}

A number of Japan-based Korean writers surfaced in the postwar era and their works comprise what is known today as zainichi Korean literature. ${ }^{2}$ Unfortunately, the genre is largely overlooked, in the fields of both Japanese studies and postcolonial studies, even though it offers a rich exposé of minority life in postwar Japan and can facilitate an under- 
standing of the lived experience of colonialism and both Japanese and American imperialism as well as racism. In general, novels by first-generation writers such as Kim Sa Ryang, Kim Tal Su, and Chong Sung Bak take up the broad themes of Japanese colonialism, American imperialism, the Korean War, and unification. By contrast, novels by secondgeneration writers such as Lee Hoe Sung, Kin Kakuei, Lee Yang Ji, Yang Soo Gil, and Tsuka Kohei, to name just a few, generally focus on racism and poverty in Japan, violence in the home, the sense of alienation zainichi Koreans tend to feel in both Japan and Korea, and the recovery of 'Korean-ness' or identity fragmentation and formation. Third and fourth-generation writers, such as Yū Miri, Gen Getsu, and Kaneshiro Kazuki, tend to take up a highly diversified range of issues in their novels. While their novels are unmistakably informed by the political, cultural, and familial implications of what it means to be a zainichi Korean in Japanese society, there is some debate as to the legitimacy of labeling them 'zainichi Korean' literature. This is partly because of a seeming lack of attention to issues of 'ethnicity' and related political concerns in their literature, but also because of debates surrounding the significance of categorizing writers by their ethnicity and concerns to the degree that such categorization further 'minoritizes' or 'exoticizes' those writers.

This paper offers an analysis of the first narrative of the genre to reach a Japanese audience outside of the literary establishment, Kinuta o utsu onna [The cloth fuller] ${ }^{3}$, written in 1971 by second-generation zainichi Korean Lee Hoe Sung (born 1935). This poignant story, based upon the life and death of the author's mother, won Lee the esteemed Akutagawa Prize for Belles Lettres in $1971 .{ }^{4}$ Lee thus achieved widespread recognition amongst the Japanese public as both the first 'foreigner' to win this prestigious prize and as the first zainichi Korean writer to articulate issues clearly specific to diasporic Korean family life in Japan. ${ }^{5}$ Indeed, according to Stanford-based scholar Christopher Scott, the awarding of the Akutagawa Prize to Lee "signaled the canonization of the genre of zainichi Korean literature" (Scott 22 May 2001, Interview). Itō (1972: 20) adds that it "heralded a major shift in the perception of zainichi Koreans and zainichi Korean literature amongst Japanese". Significantly, Lee also achieved a heroic stature amongst zainichi Koreans as the first zainichi Korean writer to win the coveted prize. Film director Kim Su Gil made the comment, "After Lee won the Akutagawa Prize, he was very powerful. All of us looked to Lee. He was virtually omnipotent" (Kim 25 May 2001, Interview).

The semi-autobiographical Kinuta o utsu onna is a folkloric story of the life of zainichi Korean Chang Suri, as remembered by her son and step-mother, following her untimely death at the age of thirty-three. Although Suri's biological mother plays a role in the unfolding of the nar- 
rative, as will be discussed later, she is absent from Suri's life from a very early age. Indeed, throughout the novel, it is Suri's step-mother that appears as her primary care-giver, as a parent to her, along with her father. As a young woman in the 1920s, Suri bids farewell to her griefstricken parents and leaves colonized Korea for metropolitan Japan, ostensibly to avoid becoming a cloth fuller like the other women in her village. In northern Japan she marries a Korean with whom she has a turbulent relationship marked by violence as well as warmth. He takes her further north to the Japanese colonial outpost of Karafuto, now known as Sakhalin, in Siberia, where he works as a miner while she raises their three sons. When their youngest son Jojo is six, he goes to Korea with Suri for a memorable visit, after which her step-mother and father accompany them back to Karafuto to settle there, albeit in conditions of poverty and hardship characteristic of early 1940s fascist Japan.

Other notable works written by Lee in the 1960s and 1970s offer heartrending portraits of family strife: disorder, domestic violence, sorrow, discrimination, and internal conflict, all of which, according to Takeda Seiji, accurately characterized archetypal zainichi Korean home life from the late 1940s to the 1960s (Takeda 1995: 40). ${ }^{6}$ In describing the family life of zainichi Koreans in Japan, Lee Hoe Sung wrote what Hayashi Koji calls, "A literature born of grief" (Hayashi 1986: 16). In a threeway discussion with writer Kim Sok Pom and Japanese literary Nobel Prize winner Oe Kenzaburo, Lee said, "Family problems have more than likely been experienced by all zainichi Koreans of my generation. I want to take up the issue of the family, from a second-generation zainichi Korean point of view, to facilitate a process of self-discovery" (in Takeda 1995: 16).

\section{The 'little narrative' - the personal is political}

The recovery of the sphere of the personal as a path to self-discovery is reminiscent of discourses of the women's movement of the 1960s and 1970s when the personal was declared to be political. American feminist Carol Hanisch made the phrase famous in an essay of the same name, published in 1970 in Notes from the Second Year: Women's Liberation: Major Writings of the Radical Feminists. She was frustrated that women "were belittled for trying to bring personal problems into the public arena, especially body issues like sex, menstruation, appearance, abortion, housework, and child care which were deemed 'personal'" (Hanisch 1970: 76-78). She called attention to these issues to promote a greater understanding of both women's experience and the mechanisms and discourse of male supremacy. In short, the slogan was a call for women to see their embodied lived realities as valuable and significant - even if 
they were not valued in the public sphere. Through a process of investigating their own everyday lives and collective reflection, women identified their individual experiences as shared, as social, and then in turn as political (Pateman 1989; Fine et al. 2004). The notion that the personal is political went some way toward describing women's subordination and oppression, as well as acting as a call to collective action.

Whilst initially arising in the realm of gender issues, the concept that 'the personal is political' can easily be transposed onto issues of race. This transposition provides a valuable lens through which to gain insight into the Korean experience in Japan, which in turn enables a deeper understanding of Lee's Kinuta o utsu onna. In Japan the dominant discourse either negates or obfuscates Japanese colonial history, as well as everyday zainichi Korean experience. However, Lee's narrative is a strategic assertion of difference which gives zainichi Koreans a bona fide presence in Japanese history and points to a politics of identity that exposes existing relations of power. Narratives of family life do not explain the whole movement of history, social life, or nationhood as a single interconnected totality or as a 'grand narrative' (Rojek and Turner 1998), rather they are 'little narratives' of personal suffering and redemption. Phillips notes that 'little narratives' are histories, marked by the gradual erosion of grand narratives of the social, that locate their significance in real life as it is lived (Phillips 1994). Generally speaking, the criticism of grand narratives has gone hand-in-hand with a project intent upon validating the little histories told by 'others' or by the 'subaltern' (Klein 1995). Scholars from a variety of disciplines have argued that the study of individual lives - i.e., 'little narratives' - over time is indispensable for meaningful social inquiry (Cremin 1988; Gardner 1994). In psychology too, life history has often been an important part of the study of personality development (Erikson 1950) and in sociology individual life histories are considered central to understanding the social order and instigating social change (White 1952; Becker 1970; Terkel 1972; Goodson 2001).

In this paper I approach Kinuta o utsu onna as exemplary of the 'little narrative', which privileges personal experience as the means to articulate identity and a sense of belonging - or alienation. ${ }^{7}$ When Lee put the story of an individual Korean woman on the Japanese stage, the private sphere of Korean home life in a Japanese colonial outpost was refracted into public space rather than left hidden. Indeed, the little narrative functions as a political impulse towards the construction of a positive Korean identity not wholly constrained by the grand narrative of Japanese colonialism. Although Lee renders the lives of Chang Suri and her family as embattled and marked by the privations of colonialism, his novella nevertheless functions as a symbol of resistance to a Japanese 
way of life by asserting a specifically Korean way of life. To lay claim to a different social identity than that offered by the Japanese state is a clear case of identity politics. Lee seems to be asserting that the Japanese master narrative - imperialist machinations of cultural cooptation outside the home will not penetrate the private sphere of the home; in short, the Japanization of this family will not take place. Here we see an insistence on self-interpretation that illustrates the dialectic between the personal and the political. ${ }^{8}$ Through the vehicle of the little narrative, Lee attempts to ground personal identity in the Korean tradition of oral and folk history and in kinship, notwithstanding extant familial problems. Indeed, as will be argued, the novella virtually replicates the Korean sinse t'aryong (i.e., a tradition of oral lamentation), which allows Lee, the author, to point to Korean-ness - discernible in the culturallyinformed experiences and Korean identity of the mother - as an anchor.

\section{Literary analysis}

\subsection{The 'sinse t'aryong'}

Kinuta o utsu onna is told in two narrative voices, one historical (Jojo as a child) and one contemporary (Jojo as an adult). The narrator Jojo supplies one kind of highly personal memory, first informed by childlike perceptions and feelings and later by mature reflection, at the same time as the grandmother's sinse t'aryong supplies collective or public memories. The memories of Suri put forward by both Jojo and his grandmother, which correspond to the private and the public, are essential to portraying Suri as a mother and, more figuratively, as the motherland. Their mutual endeavor allows Suri's mother to grieve and facilitates Jojo's search for both his private familial identity (as Suri's son) and his public ethnic identity (as a Korean).

For younger-generation zainichi Koreans in pursuit of a 'Korean identity', Lee advocates turning to first-generation Koreans for unadulterated cultural knowledge. Lee thus joins the ranks of nationalist writers elsewhere, who, according to Boehmer (1995: 192), "did not lose their connection with the teachings of the generation which had gone before [...] as a way of preserving [...] continuity with the past". Nandy similarly defines the nation's culture (1988: 812) as "the accumulated wisdom of a people or 'dialectic' between the past and the present, the dead and the living". In Kinuta o utsu onna, such a dialectic is inherent in the grandmother's sinse t'aryong, a Korean tradition of memorializing one's own or someone else's life, especially the struggles one endures, in monologue-song form, accompanied by rhythmic drumming or music and marked by weeping and emotive expressions of grief. The sinse t'aryong 
is typically performed by an elderly woman. ${ }^{9}$ The grandmother recognizes and shares the boy's need to re-encounter his mother through the sinse t'aryong, and the boy gains knowledge of his people's history through hearing it. ${ }^{10}$ In the novella, Jojo reminisces:

[Grandmother] swayed backward and forward and beat her knees rhythmically as she tearfully began the story of her beloved daughter [...] I can still remember the meter. It was such a sad requiem. It stirred up a sensation of loneliness not unlike that evoked by a reed flute drifting away. Yet, all the while, the tenor that flowed through the melody, like the current of a great river, and its tenderness, reminiscent of the fluttering leaves of an Aspen, mingled with a pulsating wrath and bitterness. It was unlike any other score, even one fashioned by a master [...] Grandmother seemed to be nodding to the spirit of her dead daughter. (Lee 1991 [1972]: 204) ${ }^{11}$

The spectacle of the grandmother's emotion is compelling. A requiem for Suri, the sinse t'aryong also functions as a requiem for Korea. According to Koreanist Beverly Nelson, "The grandmother transcends her role as a character in the story and becomes an artist [...] who is seen as a shaman, a medium in communication with the dead (mother) and the lost (culture)" (Nelson 1979: 142). Shamans perform the task of healing rifts between the living and the dead, the present and the past, by becoming mediums with the spirit world (Nelson 1979: 142). Both the grandmother, as one storyteller within the story, and Lee, as the creative force behind her character, are here likened to the shaman, and as such assume healing powers through their acts of storytelling. Lee's use of the sinse t'aryong demonstrates the power of oral tradition as an important means to heal the pain of separation from the Korean homeland, and to sustain and validate memories of it - a process which in turn helps to close the gap between the past and the present and between zainichi Koreans and their homeland.

Lee weaves the sinse t'aryong into the structure of Kinuta o utsu onna such that the novella itself virtually mimics the sinse t'aryong in style and form. Its rhythmic quality, its ephemeral mood, along with the impression that the swaying grandmother is in a trance, all evoke a cadenced musical feel. Wender makes the point that "[t]he attention Lee gives to using phonetic characters (furigana) to enable the reader to pronounce Korean names and words has the effect of accentuating the [novella's] oral/aural quality" (Wender 2005: 34). However, both Wender and Nelson are careful not to conflate a sinse t'aryong with a written narrative. ${ }^{12}$ Whilst this seems an obvious point, it discounts the fact that Lee was largely successful in his efforts to replicate this indigenous 
tradition in written form, and in so doing he succeeded in both giving the novella a Korean feel and in eulogizing the figure of the mother in a traditional Korean manner. I tend to share the views of Japanese and zainichi Korean reviewers, such as Kitada (1991 [1972]), Hayashi (20 April 2000), and poet Chong Jang (18 December 2001, Interview), all of whom argue that the novella bears marked similarities to the tradition of oral lamentation, despite its formal differences. Itō, in fact, likens the entire archive of zainichi Korean literature itself to a sinse t'aryong (Itō 1972: 27). After all, the sinse t'aryong, precisely because it is a lamentation, is a fitting medium through which to convey zainichi Korean experience.

For Lee the sinse t'aryong was a powerful and valuable way of protecting the small, local history that was in danger of being crushed by Japanese History. Through it he unearthed traces of historical consciousness and exposed the Korean identity markers embedded in the mythic oral performances of the natives. Significantly, the notion that it must be passed on to the next generation is implicit in the ritualized telling of the story. ${ }^{13}$ The recital of the sinse t'aryong thus serves to preserve the community and keep its members informed of their history. As such it is prescriptive for the novella's zainichi Korean readership. By transforming the oral tradition into a written one, Lee encourages zainichi Koreans to benefit from and appropriate traditions otherwise unavailable to them. Through the events and structure of the novella, Lee communicates the importance of filial piety, another Korean value, as well as his commitment to Korea proper. In this instance he perhaps aspires to resolve the differences between first- and second-generation zainichi Koreans mentioned in the beginning of this paper.

There is an implicit value of storytelling for those familiar with suffering. As a literary art form it provides access to ancient myths and rituals from a bygone past which allay the sadness associated with the loss of those very myths and rituals (Danow 1995: $78-79$ ). ${ }^{14}$ The specifically Korean lamentation allows Lee to point to Korean-ness - discernible in the culturally informed experiences and Korean identity of the mother as an anchor. This anchor - the mother, and by extension, the motherland and memories of it - secures the child to a solid 'home' or a cultural place of reference. Though the child must set sail on his own course, he has a cultural anchor that grounds him within himself and his Korean identity. As we turn to Kinuta o utsu onna it is apparent that the first lines of the story may be likened to the prologue of the oral tradition of the sinse t'aryong:

The day Chang Suri died was a winter day ten months before Japan's long war would end. I remember it well. I was nine years old. (Lee 1991 [1972]: 187) 
Despite the poignancy of these first lines, Lee quickly diverts the reader's attention to a number of entertaining and illuminating vignettes, all of which help to define the family as Korean. From the start Lee establishes Jojo as an average nine-year old boy, whose world is very narrowly defined by daily events. He is given cod liver oil at school but no peppermints due to 'war rations'. He enjoys riding in horse-drawn wagons. He squirms when his grandmother tries to cuddle him. He chases red roosters. He dashes out of the house when his parents fight or does the dance of the hwarang warriors to distract them (or bring about unification). $\mathrm{He}$ and his friends pinch sweet bean-bread and scurry away. These and other episodes convey the everyday life of a nine-year-old boy in Japan's colonial outpost of Karafuto.

The innocent child is unable to fathom death or its significance and is unaware that his mother has died in childbirth. He muses that "[s]he is 'just having a baby' so 'why the long faces?" He fails to comprehend that his mother will never return, and describes his leaving school early to visit the hospital and his mother's funeral as gala affairs.

A teacher approached the door. I thought it had something to do with me. I was right. Soon my teacher nodded, looked towards me and called my name saying, "Go straight to the hospital." I don't know why but I felt like it was a grand occasion, maybe because all my classmates looked up at me with envy [...] I left my seat in a high and mighty manner and felt their envious glances on my back and left the room [...] My brother was waiting for me with a worried look on his face. "Hurry up," he said angrily. "We're supposed to hurry. Don't you get it?" (Lee 1991 [1972]: 192-193)

I finally made it to the hospital and took my time in the ward [...] It was a gloomy place so when I finally found my mother's room I was about to shout for joy but when I pushed against the half open door [...] I stopped. My brother, who had arrived first, had covered his eyes with his fists [...] My father was downcast. Even so, I failed to realize that my mother had died. (Lee 1991 [1972]: 193-194)

At the funeral I acted cheerfully. If you think about it, from a little boy's point of view, a funeral is like a festival [...] Though I don't know why, it didn't seem like mom had died forever. Somehow I felt like the honored child at a festival. And the festival itself was in honor of my mother. In order to make people pay attention to me I made a pious show of offering incense at the altar and, suppressing a slight yawn, I showed myself quietly moved to tears. 
Seeing this kind of behavior in me, grandmother beat her knees and cried, "Aigō! Jojo. You really don't understand at all, do you?" (Lee 1991 [1972]: 196)

Beverly Nelson (1979: 137) aptly points to the mother as the symbol of the lost or irrecoverable motherland, but I believe that Nelson misses an important point by neglecting to recognize the boy as the symbol of the orphaned zainichi Korean. When, at the funeral, the grandmother berates Jojo, crying out, "Aigō! Jojo. ${ }^{15}$ You really don't understand at all, do you?", what may be inferred is not just the inability of the child, by virtue of his youth, to comprehend the gravity of his loss but also the inability of zainichi Koreans, by virtue of their location and lack of memories, to comprehend the loss of Korea as motherland. ${ }^{16}$ The sinse t'aryong fashioned by Lee is thus a vehicle to rectify this dearth of memory in both the fictional characters and the reading audience.

\subsection{A turn towards modernity?}

Presently, the boy begins to take notice of his grandmother's sinse t'aryong, which describes Suri's departure for Japan at the young age of eighteen and frames the narrative of her separation from Korea and ultimately her death, thus linking the events. Saying she does not want to become a cloth fuller like the other women of the village, Suri leaves home; her departure for Japan appears at this point as a kind of turn towards modernity. The following passage describing Suri's exodus is simple and poignant, pointing to the end of her youth, to the irreversible transition and uncertainty that awaits her and her parents upon their separation, the loss of country and home, and the grief and worry filling her parents' hearts.

The sun streaks hit the river dancing and it was a day you could hear the women fulling cloth [...] Suri put her belongings on her head. Her shimmering hair cascaded down her back very neatly done in two braids, tightly bound with ribbon. At the riverbed she removed her sandals and placed them in the basket on her head. She entered the shallow end and cautiously made her way into the shoal trying not to wet her ch'ima [...] and turned and looked back at the riverbank. Her mother and father were there, watching her. She hid the teardrops seeping out of her eyes, nodded to them and, with a shake of her head crossed the stream. (Lee 1991 [1972]: 207)

Suri's parents would lose her for ten years, despite her promise to return in three. Although Korea was technically 'Japan', Lee points to both the 
geographical and figurative distance between the two countries, "When Suri informed them she was moving to Hokkaido, her parents did not know what to think, having never heard of this place but, because it was up north, it seemed farther away" (Lee 1991 [1972]: 206). By and by, Suri informed her parents she had married a Korean coal miner in Hokkaido, who would be taking her to the outpost of Karafuto (later Sakhalin), the location of which her parents could not conceive. The geographic and emotional distance manifest in the passage works to challenge Japan's territorial claim to Korea and Karafuto and evokes the grief brought on by their separation, again very clearly associated with Japan's program of colonization. In this way, Suri's departure from her home in Korea can never be separated from the Japanese colonial enterprise. Her parents grieve, "Is it fate? Is it the result of Korea's devastation? Why would she want to go to that country of thieves? Wasn't it enough that they stole our land? Why did they have to steal our daughter too? Oh what a fate. Oh Suri" (Lee 1991 [1972]: 206).

Suri and her husband have three children and, in the fall of 1939, after a ten-year hiatus, she visits her parents in Korea with Jojo, now six, where they stay for one month. After this, Suri's parents return with her to Karafuto. ${ }^{17}$ It is then that the reader learns, rendered in only a few lines, the real reason for Suri's departure for Japan. It was not a turn away from tradition and towards modernity or Japanese capitalism, as had been suggested. In fact, Suri's exodus had been prompted by the unexpected return of her biological mother and her unwillingness to subject the family to further conflict. Thus, it becomes clear that Suri's parents had separated and her own mother had been exiled from home at some earlier time. She had returned over and over to try to reunite with her daughter only to be cruelly expelled by Suri's father. Finding her father alone one day, Suri says, "You understand why I left for Japan, don't you? [...] If my real mother hadn't turned up at the time I wouldn't have gone to Japan looking for work. You see, I knew there would have been another battle over me if I'd stayed" (Lee 1991 [1972]: 211). In a direct sense this passage highlights the intermediate position of the child of estranged parents, yet it also allegorizes the dilemma of the zainichi Korean caught between the two 'homes' of Japan and Korea. Suri's father's ignorance as to what has since become of his former wife, and his counsel to 'forget her', neatly corresponds to the ignorance, sense of superiority, and careless response then typical of the male vis-à-vis the female. Read allegorically, his easy dismissal of what became of his former wife (and daughter's mother) and by extension of how his daughter felt about the tragedy, conjures up the analogous betrayal of Korea and zainichi Koreans by the Japanese government. In my view, Lee attempts to convey, through the story of the brief reappearance of Suri's biological 
mother, the notion that it is not just the zainichi Korean who grieves for the motherland; it is also the motherland who grieves the loss of the zainichi Korean.

The passage alters how the reader perceives Suri's life, her agency, and the enormity of her loss. The similarity between the biological mother's fate and that of her daughter's (both being forced to leave home and both consequently losing each other), is relevant to the whole of Suri's life. Suri's step-mother, unaware of the biological mother's reappearances and feeling no less than a natural mother toward her, experiences a similar loss when Suri leaves home without warning, a loss she describes in her sinse t'aryong. Finally, Suri's children experience the pain of losing their mother at an early age, a loss which parallels the experiences of the three women and, as stated above, similarly functions as a parable for the experience of the Korean diaspora at large. Suri's lifelong estrangement from her mother goes unmentioned afterwards, conceivably as a demonstration of how indescribable and irreparable such heartbreak really is.

\subsection{Domestic and national strife}

At this point, the story increasingly turns to domestic conflict and its effect on the family. It is, in fact, the fighting of Jojo's parents and his father's violence that cause the family to fragment. Arguably, the fighting functions as an allegory of the Korean War and its aftermath - a divided country and people:

After the storm it would be hard to breathe in that house [...] My father would look put out [...] and mom would be holding her head, like a wounded animal, in the corner of the room [...] We timidly looked at our mother [...] She wore a huge gauze mask and all we could see of her bruised and battered face were her curiously lit eyes [...] Her lip, cut up so badly, had required two stitches. (Lee 1991 [1972]: 220, 224-225)

In Kinuta o utsu onna the domestic strife culminates in Suri's decision to abandon her husband and her children. The scene where she attempts this is noteworthy for the way it depicts the children's terror and the mother's anguish:

When she finished packing she [...] left out the back door. Then we knew we'd been completely abandoned. We three children all cried out to her at once. When she heard us, she stopped and sat down on her heels and stayed there. She began to look like a stranger and 
the atmosphere became colder and colder [...] We stayed still where we were too afraid to approach her. I really felt like crying [...] She finally bent forward as if to hide her face and sobbed. Not long after that she stood up as if nothing had happened and put her trunk back. Chang Suri died about ten months after that. (Lee 1991 [1972]: 225)

Kinuta o utsu onna finishes where it starts, with Chang Suri's death. Jojo recalls, "Later in life, as dad aged, I often saw him sitting in front of mother's altar. I'd come in the room unawares and he'd be whispering there" (Lee 1991 [1972]: 227). In this way, Lee communicates that Suri's life and death remained a permanent part of the family's collective memory.

\section{Conclusion}

I have argued that inherent in Lee's little narrative are two complementary movements: (i) a refusal to have the monolithic social order of Japanese imperialism overpower the private sphere of home and (ii) a commitment to preserving Korean identity. However, it is not merely Japanese colonialism that Lee is resisting through this early novella. At the time of writing, most zainichi Korean writers were focused almost exclusively on the grand narratives that defined the zainichi Korean experience in colonial and postwar Japan - narratives such as fascism, democracy (which worked for the majority Japanese but not the minority Korean), and Korean nationalism (specifically socialist) - to such an extent as to portray zainichi Koreans almost solely as 'the dispossessed'. Lee does not sidestep these issues, for he is highly cognizant of the problems facing individuals when society over-determines their lives and values, but he puts distance between sociopolitical superstructures and life as it is really lived and in this way points to a more meaningful autonomy - one that is self-directed, if you will. Lee thus offers not only a rejection of Japanese colonialism, but also a retreat from all the hyperpoliticized grand narratives of his day. According to historian Klein, "[t]o denounce meta-narratives and applaud the proliferation of local narratives is to resist totalitarian universal history and political oppression" (Klein 1995: 284). Lee's is just such an attempt: rather than promote a search for a socialist homeland, in this novella at least, the author is trying to produce a cultural history removed from grand narratives and to focus on culture and kinship as a means through which to assert individual autonomy.

While Kinuta o utsu onna privileges the little narrative, it points backwards to an untenable, edenic, pre-modern past; thus Lee pits idyllic 
memories against postcolonial anxieties. Rather than point to a range of shifting identities, or the ability to acquire an ethnic identity, as asserted by Wender in her (2005: 43) monograph Lamentation as History: Narratives by Koreans in Japan 1965-2000, it actually borders on an attempt to recover a prefigured identity. In many of his later works of fiction, Lee's characters search for clues to their Korean identity, and attempt to appropriate or recover 'Korean-ness' and modify identity markers, but not in this novella. In my reading, there is no crisis of identity for any of the characters here. In fact, I'd go so far as to argue that Lee emphasizes a unified or synthesized Korean identity as a counter-hegemonic ploy to resist assimilation and thus hybridity. Likewise, and in the same vein, my analysis of the mother's dying words to her husband, "Nagasarenaide" [Don't drift away!] (Lee 1991 [1972]: 227), differs from Wender's. She offers two layers of interpretation, writing, "The implication in this passage is that it is the father who has recognized his guilt in causing misery of his wife" along with, "we should not let victimization (and the father, as Korean, is clearly the object of oppression) breed further victimizing" (Wender 2005: 51). In my view, however, Chang Suri's final expression is one of encouragement, rather than reproach, through which she, to my understanding, communicates something like 'Don't lose yourself' or 'Live as you are - a Korean - with pride'. In fact, Chang Suri affirms the essence of who she believes him to be - a Korean man who should not be conquered by forces outside of himself.

Finally, turning to the problem of gender, perhaps Lee wanted to transcend grand narratives by bringing an understanding of women to bear on zainichi Korean history. The private individual story of a young zainichi Korean woman/mother in a Japanese colonial setting with a violent husband allegorizes the embattled situation of Korean culture and society in a fascist Japan. In this sense also, it is political. A lack of viable alternatives in the Japanese colonial economy put the husband in the under-class and he reinstated power and authority with his fist, much like the Japanese state. Instances of violence in the story take place at the domestic rather than at the national level, with the battlefield being at home. Consequently, even as Chang Suri evaded Japanese dominance in her private sphere, she could not evade the very personal ramifications of patriarchy therein.

Lee's story may implicate the paternalistic constraints that led to Chang Suri's predicament. However, at the same time it also replicates gender divisions as oppositional and incompatible. The contemporary notion that gender is socially and discursively constructed never emerges in the narrative. In fact, to some degree, Lee re-constructs gendered binaries (the male is the dominant, unrestrained, morally irresponsible bread winner or sage elder, while the female is the beautiful, virtuous but 
constrained, homemaker or hysterical harridan) rather than envisions or describes other sets of possibilities for identity construction. Such binaries fix a certain set of traits as male/female and fall into a deterministic view that ultimately legitimates the superiority of men, even if the stance is against male dominance (Kubota 2003: 36).

Nevertheless, Chang Suri is not merely presented as a static, fixed entity, or a victim; she is a complex mix of strengths and weaknesses free in some areas but coerced in others. When she leaves her village alone she defies the meta-narrative of the colonized woman to effect a possible transformation; yet she is unable to escape a violent marriage. Likewise, her husband is not entirely one dimensional; he is hearty, warm, and funny at times. Kinuta o utsu onna is not a story of pure assimilation or absolute resistance; it breaches the rules and expectations of the reader. Above all, I would argue that Lee tries to depict Chang Suri's maternal devotion - her ultimate refusal to abandon her children even in the face of violence - as a testimony to her strength of character. This is how she functions as a cultural landmark of social history. The story succeeds as a little narrative for it certainly reflects her life rooted in individual particularity and also functions as a barometer of social life.

In Kinuta o utsu onna Lee communicates that what shapes one's interior life is one's own personal experience - one's family - the little narrative. Lee's cultural depictions worked to rescue zainichi Korean culture from the pessimism of political and grand narratives. Lee's protagonists survive not as ideological thinkers but as part and parcel of the folk history handed down to them. Indeed, in Kinuta o utsu onna the grandmother's sinse t'aryong and the memories of the mother connect the boy to his personal history and have more power and influence over him than political forces. It is the family's refusal of the grand narrative of colonialism that safeguards the integrity of the characters in the story and protects their ethnic identity. Ultimately, Lee, the storyteller, thus plays the role of the cultural transmitter of an aesthetics of kinship.

Elise Foxworth, Ph.D. (E.Foxworth@latrobe.edu.au), is a lecturer in Japanese studies and language in the School of Social Sciences at La Trobe University in Melbourne, Australia. She specializes in the Japanese literature written by zainichi Koreans and has written a number of articles on writers Kim Sok Pom, Lee Hoe Sung, and Kin Kakuei. Her other research interests include exploring the intersections between cultural studies and Japanese studies and she is also engaged in literary translation. 


\section{Notes}

1. It is current practice for some scholars to refer to the author as Ri Kaisei, a Japanese transliteration of his name. However, in a personal interview, Lee Hoe Sung expressed his preference for the Korean pronunciation of his name and went on to autograph a number of his novels for me, in both Japanese and Roman letters, using 'Lee Hoe Sung'. Furthermore, Lee Hoe Sung is the transcription employed in the copyright pages of many of his novels.

2. The term 'zainichi Koreans' refers to those Koreans and/or their descendants whose presence in Japan is the direct result of Japan's thirty-five year occupation of the Korean Peninsula (1910-1945). This term distinguishes them from 'newcomer Koreans'. Some scholars use the term 'resident Korean', an abbreviation of the English translation of zainichi Korean, 'Japan-resident Korean'. However, 'resident Korean,' like its Japanese equivalent, may make sense only to Englishspeaking scholars familiar with Japan's Korean diaspora, the term being unknown to those whom it describes. The indigenous term is immediately comprehensible to any Japanese speaker and can facilitate discussion of zainichi Koreans amongst non-Japanese, Japanese, and zainichi Koreans themselves.

3. Nelson translated the title of Lee's novel as 'The Woman who ironed clothes' (1977) and Wender as 'The woman who fulled cloth' (2005: 33). I prefer 'The cloth fuller'.

4. A kinuta is an ironing stone upon which clothes were placed and packed down with a wooden paddle. Traditionally clothes were washed and 'ironed' in this way at the river.

5. In his acceptance speech Lee called attention to Kim Sa Ryang, a first-generation writer who was passed up for the prize during the colonial era saying, "I wish to accept this prize on behalf of Kim Sa Ryang. It is the first time it has been given to a foreigner. I do not underestimate its significance [...] During times of difficulty I will treasure this prize" (Bungei Shunjü: 318). Kim Sa Ryang was the first nonJapanese and zainichi Korean to become a runner up for the prize for his Hikari no naka $n i$ [Into the light] (published in 1939).

6. In August 1969 Lee published the second novel of the series Warera seishun no tojo nite [In our prime] in Gunzo, which was nominated for the 62nd Akutagawa Prize for Belles Lettres. Then in 1970, at the age of thirty-five, he published Shisha no nokoshita mono [What the dead left behind] in Gunzō and in May Shonin no inai hikari [The prophecy without a witness] in Bungaku Kai; the latter was nominated for the 63rd Akutagawa Prize for Belles Lettres. In the 1970 August and September editions of Shincho he published his very popular novel Kayako no tameni [For Kayako]. In March 1971 Lee published Seikya no yado [The blue hill lodge] in Gunzo and in June Kinuta o utsu onna, [The cloth fuller] in Geijutsu, and in November Pan choppari [Half Jap] in Bungei.

7. In critical theory, a grand narrative is sometimes also known as a master- or metanarrative, hence I use the terms interchangeably. Likewise a micro-narrative is also referred to as a local narrative or a little narrative. See, for example, Lyotard (1979: 7), Klein (1995: 279-282) or Stephens and McCallum (1998).

8. Indeed Lee's literary oeuvre at large may be viewed similarly - as an assertion of difference within the dominant Japanese literary canon.

9. The sinse t'aryong is typically performed by a woman because, according to poet Chong Jang, women, in their marginalized position in the family and society, have 'more to lament' and because they are assigned and allowed the roles of the broken-hearted and the noisemaker (Chong 2001). Sinse is pronounced 'shinse'.

10. See a discussion of oral tradition as history transformed into literature in other English language postcolonial studies in Jordan and Weedon (1995: 240-241). 
11. All of the translations that appear in this text are mine.

12. Nelson is careful to point out that the sinse t'aryong is not a written literary genre. It is rather an oral narrative tradition used to, "complain about one's bad luck, one's unhappy lot in life." She situates it within the larger category of p'ansori, a traditional Korean oral form of narrative storytelling (Nelson 1979: 137, 141142).

13. Many writers have turned to history in their search for an answer to the question of where one might find a positive identity in a racist society; two of the best known in the US are Alice Walker and Toni Morrison, who have looked to African-American cultural traditions in an attempt to authenticate a specifically black women's language and cultural history (Jordan and Weedon 1995: 239).

14. See also a discussion of Guyanese writer Wilson Harris, who apparently also recognizes the possibilities of spiritual conversion inherent in the oral tradition of storytelling (Petersen and Rutherford 1995: 186-188).

15. Aig $\sigma$ is a Korean expression of exasperation and may be translated as 'Oh my God'.

16. Boehmer (1995: 190) writes about other postcolonial writers who, like Lee, address "the sorrow of broken cultural lineages and fragmented memory under empire."

17. In Jinmen no oiwa [Stone face] (published in 1972) Lee takes up his father as the central figure. As an account of the journey Lee's family made from Korea to Karafuto, the novel may be considered a sequel to Kinuta o utsu onna.

\section{References}

Becker, Howard. 1970. Sociological work. Chicago: Aldine.

Boehmer, Elleke. 1995. Colonial and post-colonial literature migrant metaphors. Oxford \& New York: Oxford University Press.

Bungei Shunjū. March 1972. Dai-66 kai, Shōwa 46-nendo Akutagawa-shō kettei happyō: Akutagawa-shō 'Kinuta o utsu onna' Lee Hoe Sung, 'Okinawa no Shōnen' Azuma Mineo. [The announcement of the 66th annual Akutagawa Prize, 1971: The Akutagawa Prize for Belles Lettres for Lee Hoe Sung's The cloth fuller and The young Okinawan by Azuma Mineo]. 312-317.

Chong, Jang. 2001. Personal interview held in Osaka, 18 December.

Cremin, Lawrence. 1988. American education: The metropolitan experience 1876-1980. New York: Harper and Row.

Danow, David K. 1995. The spirit of carnival: Magical realism and the grotesque. Lexington, KY: The University Press of Kentucky.

Erikson, Erik H. 1950. Childhood and society. London: Imago.

Fine, Michelle, Lois Weis, Linda Powell Pruitt \& Aprils Burns (eds.). 2004. Off white: Social and political readings on power, privilege, and resistance. New York \& London: Routledge.

Gardner, James B. 1994. Ordinary people and everyday life: Perspectives on the new social history. Reading, MA: Addison Wesley.

Goodson, Ivor. 2001. The story of life history: Origins of the life history methodology in sociology. Identity 1 (2). 129-142.

Hanisch, Carol. 1970. The personal is political. In Shulamith Firestone \& Anne Koedt (eds.), Notes from the second year: Women's liberation: Major writings of the radical feminists, 76-78. New York: Radical Feminism.

Hayashi, Kōji. 1986. Kozarushū: Shoki Hyōron Shū [The monkey files: an early critique]. Tokyo: Shinkansha.

Hayashi, Koji. 2000. Personal interview held in Kawasaki, 20 April. 
Ito Naruhiko. 1972. Zainichi chosenjin bungaku to wareware [Zainichi Korean literature and us]. Bungakuteki Tachiba 7. 16-36.

Jordan, Glenn \& Chris Weedon. 1995. Cultural politics: Class, gender, race and the postmodern world. Oxford \& Cambridge, MA: Blackwell.

Kim, Sa Ryang. 1939. Hikari no naka ni [Into the light]. Tokyo: Kodansha.

Kim, Su Gil. 2001. Personal interview held in Osaka, 25 May.

Kitada, Sachie. 1991 [1972]. Foreward. In Hoe Sung Lee, Kinuta o utsu onna to Matafutatabi no michi [The cloth fuller and The beaten path], 285-297. Tokyo: Kodansha.

Klein, Kerwin Lee. 1995. In search of narrative mastery: Postmodernism and the people without history. History and Theory 34 (4). 275-298.

Kubota, Ryuko. 2003. New approaches to gender class and race in second language writing. Journal of Second Language Writing 12 (1). 31-47.

Lee, Hoe Sung. 1977. The woman who ironed clothes. Beverly Nelson (trans.). In David R. McCann (ed.), Black crane: An anthology of Korean literature (Cornell University East Asia Papers 14), 92-136. Ithaca, NY: Cornell University Press.

Lee, Hoe Sung. 1991 [1972]. Mata futatabi no michi [The beaten path] Kinuta o utsu onna [The cloth fuller]. Tokyo: Kodansha.

Lyotard, Jean-François. 1979. The postmodern condition: A report on knowledge. Manchester: Manchester University Press.

Nandy, Ashis. 1988. The intimate enemy: Loss and recovery of self under colonialism. Delhi \& Oxford: Oxford University Press.

Nelson, Beverly. 1979. Korean literature in Japan, A case study: Ri Kai Sei. In David R. McCann, John Middleton \& Edward J. Shultz (eds.), Studies on Korea in transition, 126-159. Hawaii: Centre for Korean Studies, University of Hawaii Press.

Pateman, Carole. 1989. The disorder of women: Democracy feminism and political theory. Cambridge: Polity Press.

Petersen, Kirsten Holst \& Anna Rutherford. 1995. Fossil and psyche. In Bill Ashcroft, Gareth Griffiths \& Helen Tiffin (eds.), The post-colonial studies reader, 185-189. London \& New York: Routledge.

Phillips, Dennis. C. 1994. Telling it straight: Issues in assessing narrative research. Educational Psychologist 29 (1). 13-21.

Rojek, Chris \& Brian Turner. 1998. The politics of Jean-François Lyotard. London \& New York: Routledge.

Scott, Christopher. 2001. Personal interview held in Tokyo, 22 May.

Stephens, John \& Robyn McCallum. 1998. Retelling stories, framing culture: Traditional story and metanarratives in children's literature. New York: Garland.

Takeda, Seiji. 1995. 'Zainichi' to iu konkyo [What it means to be a 'Zainichi']. Tokyo: Chikuma Gakugei Bunko.

Terkel, Studs. 1972. Working. New York: Avon.

Wender, Melissa L. 2005. Lamentation as history: Narratives by Koreans in Japan 1965-2000. Stanford, CA: Stanford University Press.

White, Robert. W. 1952. Lives in progress: A study of the natural growth of personality. New York: Dryden. 


\section{CONTEMPORARY JAPAN \\ Journal of the German Institute for Japanese Studies Tokyo}

Contemporary Japan (CJ) is the peer-reviewed biannual journal of the German Institute for Japanese Studies Tokyo (DIJ), published by De Gruyter. The international editorial board consists of distinguished Japan specialists from a broad array of disciplines. The managing editors are Japan experts working for the DIJ.

Contemporary Japan aims to contribute to the field of Japanese Studies by publishing high-quality papers that report on original research on all aspects of Japanese culture, society and economy as they relate to contemporary Japan and her historical roots. Each volume consists of one topic-specific issue and one open-topic issue. For the topic-specific issue a separate call for papers is published. Open-topic papers can be submitted at any time.

In both cases we favor submissions that report on empirical research, propose new theoretical modes or are in other ways thought-provoking and contribute to developing the field of Japanese Studies. Areas of interest include, but are not limited to, Japanese society, gender studies, cultural studies, economics and business, politics and international relations, religious studies, modern history, linguistics, literature and media studies and popular culture.

Contemporary Japan is not only available as a conventional print version. De Gruyter also offers an online version, allowing authors to provide supplementary materials to their contributions such as image files, sound files or video clips.

For information regarding submission procedures, please see www.degrutyer.com/cj or contact the managing editors at cj@ dijtokyo.org.

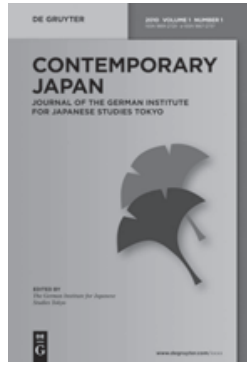

ISSN 1869-2729 (Print) ISSN 1867-2737 (Online)

Two issues per volume. 200 pp. per issue.

LANGUAGE English, German

SUBJECT Japanese Studies

READERSHIP Academics, Institutes, Libraries

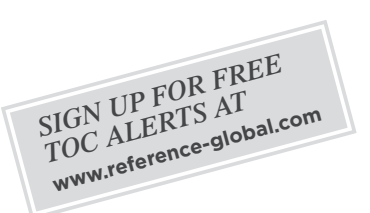

